\title{
Mucormycosis-a Fungal Infection in Patient Recovered from COVID-19
}

\author{
Kanchan Sharma $^{1}$ (D), Sudhanshu Mishra ${ }^{2, *(D)}$, Anupam Gautam ${ }^{2}$ (D), Rishabha Malviya ${ }^{3}$ (D) \\ Dr M C Saxena College of Pharmacy, Lucknow, India \\ School of Pharmaceutical Science, Rajiv Gandhi Proudyogiki Vishwavidyalaya, Bhopal, India \\ School of Medical and Allied Sciences, Galgotias University, Greater Noida, India \\ * Correspondence: msudhanshu22@gmail.com (S.M.);
}

Scopus Author ID 57217753644

Received: 15.06.2021; Revised: 18.08.2021; Accepted: 22.08.2021; Published: 11.09.2021

\begin{abstract}
Recently, a fungal disease, "Mucormycosis," has created a huge fury in everybody's mind. It is prevalent in immunocompromised individuals, such as people suffering from Covid 19, cancer, HIV, prolonged use of steroids, immunomodulators, and diabetes. It is caused by a group of molds called mucoromycetes found in damp soil, bread, decaying fruits and vegetables, compost piles, animal waste, and moist, dusty construction sites. It can invade the human body through several routes, such as inhalation, injury site, or food/water intake. The ICMR recommends wearing a mask while visiting dusty construction sites, wearing shoes, long trousers, a full sleeve shirt, and gloves when handling soils, moss, or manure, and maintaining personal hygiene, including a good scrub bath. This article further covers the history, pathogenesis, role of Iron, GRP78, and CotH, pathophysiology, geographical spread, and treatment of this rare but fatal disease. Overall, the mortality rates account for 54\%, which is further varied depending upon the patient condition, type of fungus \& body site infected, speaking of which, as reported, 96\% mortality rate alone accounts for the disseminated Mucormycosis.
\end{abstract}

Keywords: mucormycosis; fungal disease; steroids; immunosuppression; COVID-19.

(C) 2021 by the authors. This article is an open-access article distributed under the terms and conditions of the Creative Commons Attribution (CC BY) license (https://creativecommons.org/licenses/by/4.0/).

\section{Introduction}

Mucormycosis, vernacularly called "black fungus" is an opportunistic fungal infection that mainly affects people with a compromised immune system and cannot fight any foreign or environmental pathogen. It is a rare fungal infection, even fatal due to the long-term use of strong medication. It is abundantly found, and you might have seen them before in our environment, like in the soil, on the bread, decaying fruits, vegetable matters, crop debris, compost piles, animal excreta, and dusty construction sites.

As the second wave of Covid-19 hits India, and new cases rising to 3,50,000 per day, the need for strong medication enormously increases to fight the virus, but this leads to cases of rare fungal infection, which substantiate being fatal [1]. Not everyone is predisposed to black fungus but increased use of steroids (causing immunosuppression), uncontrolled diabetes mellitus, chronic obstructive pulmonary disorder (COPD), and prolonged stay at intensive care unit (ICU), Voriconazole therapy can lead to disastrous consequences. It is now classified as an epidemic by the Rajasthan, Telangana, Odisha, Tamil Nadu, Gujrat, and UT of Chandigarh as of May 21, 2021 
"Zygomycosis" an alternative word used for "Mucormycosis" is an infection caused by fungi, in the order Mucorales, mostly species are Mucor, Rhizopus, Absidia, and Canninghamella genera are most linked [2].

Mucormycosis can be classified based on site of infection into five different types, given in table 1.

Table 1. Various types of mucormycosis with risk group, transmission, and symptoms.

\begin{tabular}{|c|c|c|c|}
\hline Types & Risk Group & Transmission & Symptoms \\
\hline $\begin{array}{l}\text { Rhino-cerebral (sinus and } \\
\text { brain) Mucormycosis }\end{array}$ & $\begin{array}{l}\text { It occurs in incapacitated } \\
\text { patients, specially DKA and } \\
\text { those undergoing } \\
\text { hematopoietic stem cell } \\
\text { transplant }\end{array}$ & $\begin{array}{l}\text { - Rhino-cerebral } \\
\text { Mucormycosis is the most } \\
\text { common form the diseases } \\
\text { - Attained from: } \\
\text { a. Perineural spread } \\
\text { b. Proliferation through } \\
\text { the nasal cavity }\end{array}$ & $\begin{array}{l}\text { - One side facial } \\
\text { swelling, ulceration and } \\
\text { necrosis } \\
\text { - Headache } \\
\text { - Nasal or sinus } \\
\text { congestion } \\
\text { - Eyes or facial pain } \\
\text { - Fever } \\
\text { - Blurry vision } \\
\text { - Vision loss } \\
\text { - } \quad \text { Bulging eyes }\end{array}$ \\
\hline $\begin{array}{l}\text { Pulmonary } \\
\text { Mucormycosis }\end{array}$ & $\begin{array}{l}\text { Patients with neutropenia } \\
\text { and those undergone stem } \\
\text { cell transplant }\end{array}$ & $\begin{array}{l}\text { Attained by: } \\
\text { a. Inhalation } \\
\text { b. Hematogenous spread } \\
\text { c. Lymphatic spread }\end{array}$ & $\begin{array}{l}\text { - Fever } \\
\text { - Cough } \\
\text { - Chest pain } \\
\text { - Shortness of breath } \\
\text { (dyspnea) } \\
\text { Hemoptysis }\end{array}$ \\
\hline $\begin{array}{l}\text { Gastrointestinal } \\
\text { Mucormycosis }\end{array}$ & $\begin{array}{l}\text { Patients suffering from } \\
\text { malnourishment, AIDS, } \\
\text { Organ transplant recipients, } \\
\text { children, and infants }\end{array}$ & $\begin{array}{ll}\text { - } & \text { Rare occurrence } \\
\text { - } & \text { Attained by: } \\
\text { a. } & \text { Ingestion of fungi }\end{array}$ & $\begin{array}{l}\text { - Abdominal pain } \\
\text { - } \quad \text { Abdominal distension } \\
\text { - Nausea } \\
\text { - } \quad \text { Vomiting } \\
\text { bleeding } \\
\text { hematochezia }\end{array}$ \\
\hline $\begin{array}{l}\text { Cutaneous } \\
\text { Mucormycosis }\end{array}$ & $\begin{array}{l}\text { It occurs when there is a skin } \\
\text { injury due to surgery, burns, } \\
\text { and wounds. }\end{array}$ & $\begin{array}{l}\text { Attained by: } \\
\text { a. Disturbance in the } \\
\text { physiological skin barrier } \\
\text { b. Trauma } \\
\text { c. Contaminated surgery } \\
\text { dressing }\end{array}$ & $\begin{array}{l}\text { - Skin ulceration and } \\
\text { necrosis } \\
\text { - Skin redness } \\
\text { - Warmth } \\
\text { - Numbness } \\
\text { - The area may turn } \\
\text { black } \\
\text { - Pain around the } \\
\text { affected area }\end{array}$ \\
\hline $\begin{array}{l}\text { Disseminated } \\
\text { Mucormycosis }\end{array}$ & $\begin{array}{lr}\text { Patients } & \text { on } \\
\text { immunosuppressants } & \text { and } \\
\text { corticosteroids. } & \end{array}$ & $\begin{array}{l}\text { Attained by hematogenous } \\
\text { spread }\end{array}$ & $\begin{array}{l}\text { - The brain is the most } \\
\text { affected site of } \\
\text { dissemination } \\
\text { - Seizures } \\
\text { - Strokes } \\
\text { - Paralysis } \\
\text { - Myocardial necrosis } \\
\text { - Typically occurs in } \\
\text { patients who are suffering } \\
\text { from other medical } \\
\text { condition } \\
\text { - Patients suffer from } \\
\text { mental status change or } \\
\text { coma }\end{array}$ \\
\hline
\end{tabular}

The first-ever case of Mucormycosis was reported over 130 years ago, around 1876 by Furbringer, specifically the Pulmonary Mucormycosis. Being airborne, Fungal spores can be found on practically any human surface that comes into touch with air, particularly the mucosa of the upper and lower airways [3]. The symptoms include pain, swelling, redness around the 
eyes and/or nose, fever, nasal congestion, coughing, headache, shortness of breath, bloody vomit, and altered mental status, as advised by the Indian Council of Medical Research.

\section{History}

Mucormycosis was formerly known as "Zygomycosis" was consequently used by an American pathologist R.D. Baker to indicate a mycosis caused by some members of Mucorales. The first case in human beings was reported in 1885 by Arnold Paltauf, and the first observation of rhino-orbital cerebral Mucormycosis was in 1943. The first case of Mucormycosis possibly was explained by Friedrich Kuchenmeister in 1855, which further was described as lung disease in 1876. In 1884, Lichtheim recognized the growth and expansion of the disease in rabbits and explained the involvement of two species: Mucor corymbifera \& Mucor rhizopodiformis, which later were known as Lichtheimia \& Rhizopus, respectively [4].

In 1943, three cases were associated with poorly controlled diabetes with severe sinus, brain, and eye involvement. Later in 1953, a species was isolated from the Indian forest soil, Saksenaea vasiformis, which was found to cause several cases of primary cutaneous Mucormycosis. Further, in 1979 P.C. Misra, K.J. Srivastava, and K. Lata examined the Indian mango orchard from northern India, where they isolated Apophysomyces elegans. The agent made up to $32 \%$ of zygomycetes, which later was found to be the major cause of Mucormycosis [5]. Throughout this part of the globe, A. elegans was possibly a developing zygomycete. In general, however, most developing-country centers underestimate the importance of fungal infections due to a lack of awareness. Since then, several Mucorales instances have been reported.

It was first recorded in the United States in 1955, and it was assumed to be a new disease caused by the use of antibiotics, ACTH, and steroids. Potassium iodide was the only treatment accessible until the latter half of the twentieth century [6]. Patients diagnosed with subcutaneous Mucormycosiwere treated with a saturated potassium iodide solution, and the lesion vanished after 10 weeks with no side effects.

Over the years, the growth of Mucormycosis has increased with high rates of mortality, although Mucormycosis of any form- cerebral, cutaneous, rhinocerebral, intestinal, or pulmonary is still rare [7].

\section{Pathogenesis}

Mucormycosis, earlier known as Zygomycosis, gains entry through the lungs (inhalation) via ingestion of contaminated food, water and through scraped skin. This results in different types of Mucormycosis.

Firstly, the mucor spores must escape their assassination from the local phagocytes and macrophages to incubate and further develop into hyphae. Hyphae is the angioinvasive form of fungal infection that sooner or later propagate and spread to other organs [8].

Secondly, the main influencing factor for the growth and propagation of Mucormycosis is iron overload. Iron is an essential element for Mucorales since it promotes growth, virulence, hyphal development and increases the ability of the pathogen to cause the disease (pathogenicity).

Thirdly, the mucor spores are efficient in causing quick and rapid onset of tissue infarction the localized necrosis due to inadequate blood supply, hemorrhage following thrombosis by invasion in the tissue bed [9]. 
Mucormycosis can forcefully invade blood arteries, where it interacts and interacts with endothelial cells via the particular host receptor GRP78 (Glucose regulator protein 78). GRP78 was first identified as a heat shock protein that also plays a role in stress responses. During an invasion in the tissue bed, this opportunistic fungus links to a GRP78 to convey the signal through a ligand, and endothelium belongs to the spore covering the CotH protein family. In the Mucorales, the CotH protein is found in abundance. The most commonly isolated Mucorales from the patients are Rhizopus, Mucor, and Lichtheimia, containing 3-7 copies of CotH. Together, this information points to the unique relation and collaboration between Mucorales CotH and tissue GRP78 receptor [10].

Mucormycosis can occur in DKA (diabetic ketoacidosis) and deferoxamine-treated individuals due to elevated levels of serum glucose, iron, and -hydroxybutyric acid (BHB) which aids fungal growth, development and increases the expression of GRP78 receptor and CotH protein. Mucorales' ability to infiltrate host tissue is also boosted as a result of this. Furthermore, virulence factors like enzyme and toxin production may be involved [11]. The following figure 1.0 shows a diagrammatic representation of the pathogenesis of Mucormycosis.

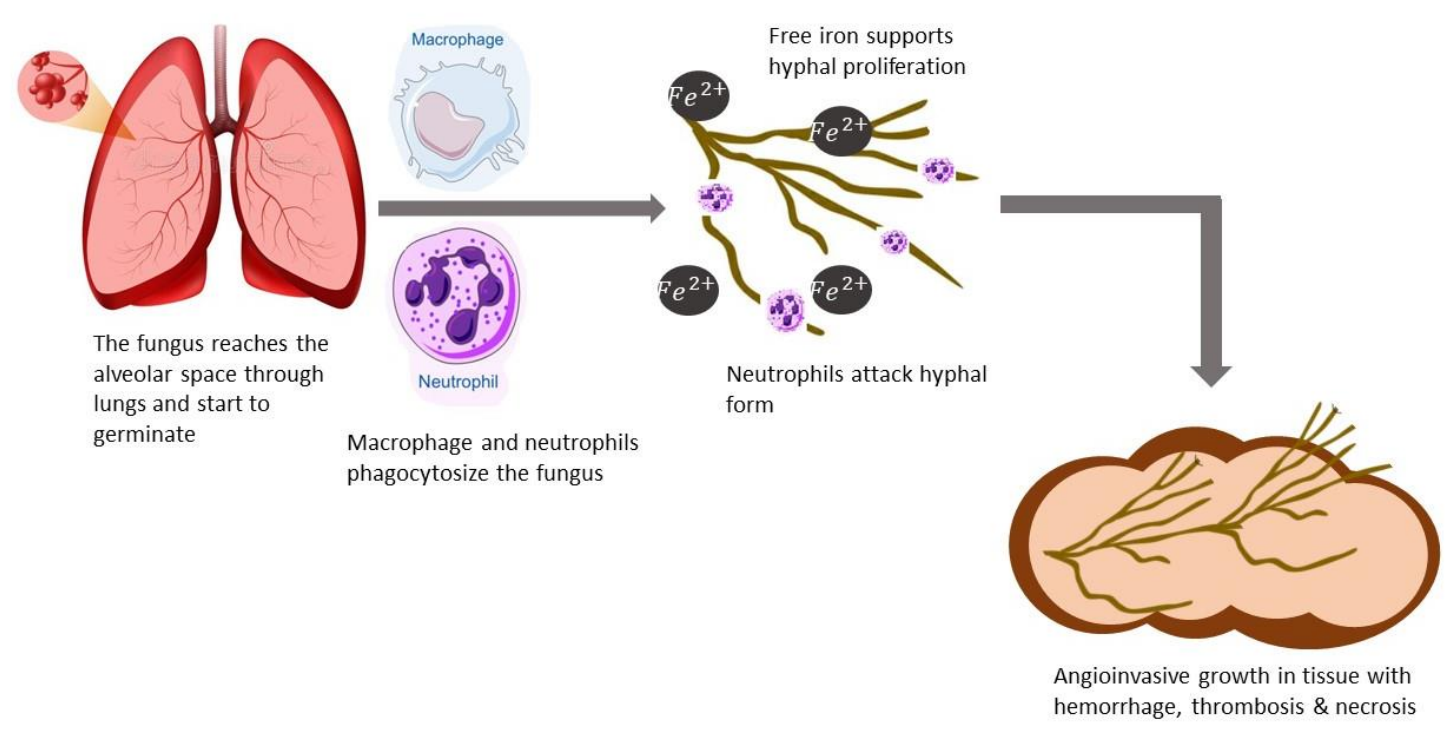

Figure 1. Pathogenesis of mucormycosis.

\subsection{Pathophysiology.}

The immune system is of two types, innate immune system and adaptive immune system, and both types are capable of fighting the fungal infection. Macrophages, dendritic cells, neutrophils, and complementary fixation are part of the innate immune system, whereas T helper cells, TH1 cells, and TH17 cells are part of the adaptive immune system. Phagocytosis is also a strong defense against the fungi, but when we talk about the pathogenesis, it is the TH1 cell that orchestrates a strong response to produce the interferon-gamma (IFN-Y), which is important for optimal macrophage activation that further associate for protection against the fungal infection by increasing the capability of phagocytosis [12].

The TH17 cell, a subtype of T helper cell, is specialized for fighting fungal infection. It secretes a molecule called IL-17 (interleukin 17) of cytokine that induces and mediates proinflammatory responses. This cytokine plays a vital role in airway remodeling. IL-17 activates signaling through the IL-17 receptor, which induces other proinflammatory cytokines, 
antimicrobial peptides, and neutrophil chemokines that are important for antifungal activity. It is found that when there is a fungal infection, the TH cells get differentiated into this specific subtype (TH17 cell) through a specific cytokine signaling via IL-6 and TGF- $\beta$. These special cytokines are secreted by dendritic cells and macrophages. When the dendritic cells and macrophages sense the presence of fungal infection or funguses like Mucormycosis, they signal these TH cells and push them to get differentiated or become this specific subtype combat this fungal infection [13].

The high incidence of this ubiquitous environmental fungi with DKA (diabetic ketoacidosis) is yet to be determined, but we know that this organism possesses the ability to get a hold of the iron from the host. Iron is an essential element required for the growth and development of the cell and plays a vital role in many bodily functions, and so the pathogen aims to get this iron from the host via multiple processes [14]. The limiting of iron in the host body is also a strong defense against the fungus. It was seen in a study that iron starvation and, thereby, undernourishment enhances apoptosis in Rhizopus oryzae.

The only challenge seen in the current scenario is with the severely compromised immune system, a patient undergoing AIDS/cancer/recovering from COVID-19. The immune system is very weak, thereby increasing the chances of having these secondary fungal infections.

\section{Treatment}

The treatment procedure includes antifungal medication such as Amphotericin B, Echinocandin, Posaconazole, and Isavuconazole via intravenous route and Posaconazole and Isavuconazole via the oral route. Surgical debridement is the second step, where the infected tissue is removed by surgery to prevent the spreading further.

Amphotericin B is the first-line drug of choice; successively, Posaconazole and Isavuconazole are prescribed as salvage therapy. The main disadvantage in managing the infection is the protocol's gap in treatment and conduct and the economical oblige of patients who cannot afford liposomal Amb [15].

The treatment is not economical as antifungal therapy with either Liposomal Amphotericin-B or Amphotericin-B injections administered for a 14- 21-day period in a hospital. One injection dose of Amphotericin-B costs anywhere in the range of ₹6,000-₹9,000. A DCGI approved AIIMS, and ICMR recommended Mankind Pharma launches posaconazole Gastro-resistant tablets under the name " Posaforce 100" to treat black fungus.

\subsection{Other treatment.}

The use of adjunctive hyperbaric oxygen suppresses (HBO) therapy for rhino-cerebral Mucormycosis is seen to be a promising medical modality [16]. Hyperbaric oxygen suppresses and overpower fungal growth in vitro and is seen as a concept significant in curing Mucormycosis by reducing tissue hypoxia and acidosis that escort invasion of fungal infection; moreover, the adverse effect associated with the therapy is minimal.

\subsection{Herbal treatment.}

One teaspoon Gudichi powder is mixed with one teaspoon neem powder and one teaspoon turmeric powder, mix uniformly, and dispersed into the half glass of water. Mix them 
well and drink them three times a day. Traditionally Tinospora cordifolia (Gudichi) is known for its jwarahara activity (antipyretic activity), anti-oxidant, antimicrobial, anti-toxic, antidiabetic, anti-stress, and wound healing activity. The phytoconstituents present in neem have anti-inflammatory, antiarthritic, antipyretic, hypoglycaemic, Antifungal, spermicidal, antimalarial, antibacterial, and Diuretic properties [17]. Turmeric has anti-inflammatory properties, blood purifiers, choleretic and cholagogue action, and liver diseases. Curcuminoids have an antiphlogistic activity that is due to the inhibition of leukotriene biosynthesis. arTurmerone has antisnake venom activity and blocks the hemorrhagic effect of the venom. Along with this, if one observes external symptoms of black fungus on the nose, one can immediately apply a mixture of neem oil, chaulmoogra oil, and sesame oil in equal parts on the infected area around 6 times a day. This will lead to a remarkable reduction in black fungal within 4-5 days [18]. Chaulmoogra oil has ethyl esters and salts of hydnocarpic and chaulmoogric acids, useful in treating leprosy and other skin diseases. Plants with antifungal properties can also be used such as seeds of Alpinia galangal, rhizomes of Zingiber officinalis, leaves of Aegle marmelos, Ananas comosus, Blumea balsamifera, Camptotheca acuminate, etc.

\section{Prevention}

Wear a mask when visiting dusty construction sites-wearing shoes, long trousers, long sleeves shirt, and gloves while handling soil (gardening), moss, and manure and also maintain personal hygiene, including a thorough scrub bath-avoiding direct contact with the waterdamaged construction and safeguarding skin, feet, and hands when possible. In a high-risk group such as organ transplant, antifungal drugs may be given as a preventative. Nasal care and good sanitation are the sole methods by which to keep the infection trapped. Thus, it is advised and instructed to keep your sugar levels under control and be alert about the symptoms to start immediate treatment and management in case of infection $[19,20]$.

\section{Environmental Factors Causing Mucormycosis}

\subsection{Indoor conditions.}

Leaky pipes and cracks in the basement walls that allow groundwater to permeate and breach the basement may cause high humidity and/or moisture content. Flooding is another source of moisture in the basement, which causes the water to go directly down to the basement and dry slowly owing to a lack of proper ventilation. This creates a favorable environment for fungal growth [21]. Since these areas have high moisture content and substrates, fungi can thrive in the kitchen and bathroom units of a building.

\subsection{Outdoor conditions.}

Fungi from the outside enter a building through the ventilation system. Residue oil of the ventilation system Ducts can also retain dust and provide nutrients for fungal development, which can be carried indoors via the ventilation system. Mucormycetes are found in the environment and enter the human body through artificial oxygen support given to COVID-19 patients or other environmental variables such as the use of polluted water to make medical oxygen [22]. 


\section{Spread of Black Fungus Across the World}

In COVID patients, there has been an increasing tendency for fungal infection. During the SARS outbreak, this was also recorded to some extent. Mucormycosis can be exacerbated by uncontrolled hyperglycemia caused by COVID-19 [23]. According to a report, mucormycosis is a severe and life-threatening infection with a $54 \%$ overall death rate that varied based on the patient's state, kind of fungal infection, and afflicted body place.

According to the findings, patients with a sinus infection had a $46 \%$ mortality rate, while patients with a lung infection had a $76 \%$ mortality rate. The mortality rate for patients with disseminated Mucormycosis was $96 \%$. The survival rate for instances that were not treated was as low as $3 \%$ (8 out of 241 patients) and as high as $61 \%$ (324 out of 532 patients) for cases treated with amphotericin B deoxycholate, according to the report. Furthermore, cases treated with surgery alone had a $57 \%$ survival rate (51 of 90 patients), while those treated with antifungal medication and surgery had a $70 \%$ survival rate (328 of 470 patients) [24-26].

Talking about the outbreak that happened in India, the cases reported are 8,848 so far and account for $71 \%$ of total black fungus cases worldwide, as shown in figure 2 . States like Gujrat has reported a maximum of 2,281 mucormycosis cases, followed by Maharashtra (2,000), Andhra Pradesh (910), Madhya Pradesh (720), Rajasthan (700), Karnataka (5,00), Haryana (250), Delhi (197), Punjab (95), Chhattisgarh (87), Bihar (56), Tamil Nadu (40), Kerala (36), Jharkhand (27), Odisha (15).

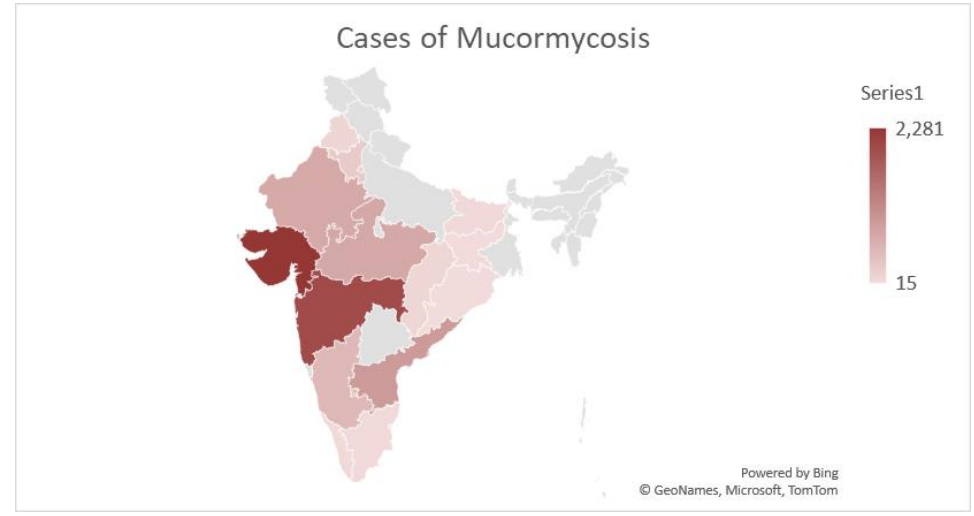

Figure 2. Cases of mucormycosis all over India.

\section{Conclusion}

Mucormycosis is a fungus that affects immunocompromised persons, such as those recuperating from Covid 19, cancer, HIV, organ transplant, stem cell transplant, long-term corticosteroid use, diabetes (DKa), and so on. It is caused by a group of molds called mucoromycetes that is abundantly found in the natural environment like the soil, manure, decaying matter, compost piles, animal excreta, crop debris, and indoor in the kitchen and bathroom where moisture retains. Mucormycosis is a non-contagious disease but has an overall mortality rate of $54 \%$, which is further varied depending upon the patient condition, type of fungus, and body site infected, as reported $96 \%$ mortality rate alone to account for the disseminated Mucormycosis. It is the third most common invasive fungal infection that can infect or damage its host tissue but can be controlled by identification of the organism in tissue by histopathology with culture confirmation, biopsy. The test may include culture and direct detection of the fungus in the lung fluid, blood, serum, plasma, and urine. The therapeutic drug and proper prevention and care should be needed for the patient to recover from COVID-19. 


\section{Funding}

This research received no external funding.

\section{Acknowledgments}

\section{Authors are highly thankful to Dr. M C Saxena College of Pharmacy, Lucknow, India, School of Medical and Allied Sciences, Galgotias University, Greater Noida, India, and School of Pharmaceutical Science, RGPV, Bhopal, India, for providing support to write this article.}

\section{Conflicts of Interest}

The authors declare no conflict of interest.

\section{References}

1. Singh, A.K.; Singh, R.; Joshi, S.R.; Misra, A. Mucormycosis in COVID-19: A systematic review of cases reported worldwide and in India. Diabetes \& Metabolic Syndrome: Clinical Research \& Reviews 2021, 15, https://doi.org/10.1016/j.dsx.2021.05.019.

2. Mekonnen, Z.K.; Ashraf, D.C.; Jankowski, T.; Grob, S.R.; Vagefi, M.R.; Kersten, R.C.; Simko, J.P.; Winn, B.J. Acute Invasive Rhino-Orbital Mucormycosis in a Patient With COVID-19-Associated Acute Respiratory Distress Syndrome. Ophthalmic Plastic \& Reconstructive Surgery 2021, 37., https://dx.doi.org/10.1097\%2FIOP.0000000000001889.

3. Goldstein, E.J.C.; Spellberg, B.; Walsh, T.J.; Kontoyiannis, D.P.; Edwards, J., Jr.; Ibrahim, A.S. Recent Advances in the Management of Mucormycosis: From Bench to Bedside. Clinical Infectious Diseases 2009, 48, 1743-1751, https://doi.org/10.1086/599105.

4. Veisi, A.; Bagheri, A.; Eshaghi, M.; Rikhtehgar, M.H.; Rezaei Kanavi, M.; Farjad, R. Rhino-orbital mucormycosis during steroid therapy in COVID-19 patients: A case report. European Journal of Ophthalmology 2021, https://doi.org/10.1177\%2F11206721211009450.

5. Ibrahim, A.S.; Spellberg, B.; Edwards, J., Jr. Iron acquisition: a novel perspective on mucormycosis pathogenesis and treatment. Current opinion in infectious diseases 2008, 21, 620-625, https://dx.doi.org/10.1097\%2FQCO.0b013e3283165fd1.

6. Kontoyiannis, D.P.; Lewis, R.E. How I treat mucormycosis. Blood 2011, 118, 1216-1224, https://doi.org/10.1182/blood-2011-03-316430.

7. Tedder, M.; Spratt, J.A.; Anstadt, M.P.; Hegde, S.S.; Tedder, S.D.; Lowe, J.E. Pulmonary mucormycosis: results of medical and surgical therapy. The Annals of thoracic surgery 1994, 57, 1044-1050, https://doi.org/10.1016/0003-4975(94)90243-7.

8. Waizel-Haiat, S.; Guerrero-Paz, J.A.; Sanchez-Hurtado, L.; Calleja-Alarcon, S.; Romero-Gutierrez, L. A Case of Fatal Rhino-Orbital Mucormycosis Associated With New Onset Diabetic Ketoacidosis and COVID19. Cureus 2021, 13, https://dx.doi.org/10.7759\%2Fcureus.13163.

9. Lee, F.Y.W.; Mossad, S.B.; Adal, K.A. Pulmonary Mucormycosis: The Last 30 Years. Archives of Internal Medicine 1999, 159, 1301-1309, https://doi.org/10.1001/archinte.159.12.1301.

10. Kwon-Chung, K.J. Taxonomy of Fungi Causing Mucormycosis and Entomophthoramycosis (Zygomycosis) and Nomenclature of the Disease: Molecular Mycologic Perspectives. Clinical Infectious Diseases 2012, 54, S8-S15, https://doi.org/10.1093/cid/cir864.

11. Cornely, O.A.; Alastruey-Izquierdo, A.; Arenz, D.; Chen, S.C.A.; Dannaoui, E.; Hochhegger, B.; Hoenigl, M.; Jensen, H.E.; Lagrou, K.; Lewis, R.E.; Mellinghoff, S.C.; Mer, M.; Pana, Z.D.; Seidel, D.; Sheppard, D.C.; Wahba, R.; Akova, M.; Alanio, A.; Al-Hatmi, A.M.S.; Arikan-Akdagli, S.; Badali, H.; Ben-Ami, R.; Bonifaz, A.; Bretagne, S.; Castagnola, E.; Chayakulkeeree, M.; Colombo, A.L.; Corzo-León, D.E.; Drgona, L.; Groll, A.H.; Guinea, J.; Heussel, C.-P.; Ibrahim, A.S.; Kanj, S.S.; Klimko, N.; Lackner, M.; Lamoth, F.; Lanternier, F.; Lass-Floerl, C.; Lee, D.-G.; Lehrnbecher, T.; Lmimouni, B.E.; Mares, M.; Maschmeyer, G.; Meis, J.F.; Meletiadis, J.; Morrissey, C.O.; Nucci, M.; Oladele, R.; Pagano, L.; Pasqualotto, A.; Patel, A.; Racil, Z.; Richardson, M.; Roilides, E.; Ruhnke, M.; Seyedmousavi, S.; Sidharthan, N.; Singh, N.; Sinko, J.; Skiada, A.; Slavin, M.; Soman, R.; Spellberg, B.; Steinbach, W.; Tan, B.H.; Ullmann, A.J.; Vehreschild, J.J.; Vehreschild, M.J.G.T.; Walsh, T.J.; White, P.L.; Wiederhold, N.P.; Zaoutis, T.; Chakrabarti, A. Global guideline for the diagnosis and management of mucormycosis: an initiative of the European Confederation of Medical Mycology in cooperation with the Mycoses Study Group Education and Research Consortium. The Lancet Infectious Diseases 2019, 19, e405-e421, https://doi.org/10.1016/S1473-3099(19)30312-3. 
12. He, J.; Sheng, G.; Yue, H.; Zhang, F.; Zhang, H.-L. Isolated pulmonary mucormycosis in an immunocompetent patient: a case report and systematic review of the literature. BMC Pulmonary Medicine 2021, 21, 1-8, https://doi.org/10.1186/s12890-021-01504-8.

13. Yamin. H.S.; Alastal. A.Y. Pulmonary Mucormycosis over 130 years: a case report and literature review. Turk Thorac J 2017, 18, https://dx.doi.org/10.5152\%2FTurkThoracJ.2017.16033.

14. Muthu, V.; Agarwal, R.; Dhooria, S.; Sehgal, I.S.; Prasad, K.T.; Aggarwal, A.N.; Chakrabarti, A. Has the mortality from pulmonary mucormycosis changed over time? A systematic review and meta-analysis. Clinical Microbiology and Infection 2021, 27, 538-549, https://doi.org/10.1016/j.cmi.2020.12.035.

15. Steinbrink, J.M.; Miceli, M.H. Mucormycosis. Infectious Disease Clinics of North America 2021, 35, 435452, https://doi.org/10.1016/j.idc.2021.03.009.

16. Reid, G.; Lynch, J.P.; Fishbein, M.C.; Clark, N.M. Mucormycosis. Semin Respir Crit Care Med 2020, 41, 099-114, https://doi.org/10.1055/s-0039-3401992.

17. Sharma, S.; Grover, M.; Bhargava, S.; Samdani, S.; Kataria, T. Post coronavirus disease mucormycosis: a deadly addition to the pandemic spectrum. The Journal of Laryngology \& Otology 2021, 135, 442-447, https://doi.org/10.1017/S0022215121000992.

18. Alqarihi, A.; Gebremariam, T.; Gu, Y.; Swidergall, M.; Alkhazraji, S.; Soliman Sameh, S.M.; Bruno Vincent, M.; Edwards John, E.; Filler Scott, G.; Uppuluri, P.; Ibrahim Ashraf, S.; Alspaugh, J.A. GRP78 and Integrins Play Different Roles in Host Cell Invasion during Mucormycosis. MBio 2020, 11, e01087-01020, https://doi.org/10.1128/mBio.01087-20.

19. Brunet, K.; Rammaert, B. Mucormycosis treatment: Recommendations, latest advances, and perspectives. Journal de Mycologie Médicale 2020, 30, https://doi.org/10.1016/j.mycmed.2020.101007.

20. Ravani, S.A.; Agrawal, G.A.; Leuva, P.A.; Modi, P.H.; Amin, K.D. Rise of the phoenix: Mucormycosis in COVID-19 times. Indian Journal of Ophthalmology 2021, 69, 1563-1568, https://doi.org/10.4103/ijo.IJO_310_21.

21. Prabhu. R.M.; Patel. R. Mucormycosis and entomophthoramycosis: a review of the clinical manifestations, diagnosis and treatment. Clin Microbiol Infect 2004, 10, 31-47, https://doi.org/10.1111/j.14709465.2004.00843.x.

22. Spellberg, B.; Edwards, J.; Ibrahim, A. Novel Perspectives on Mucormycosis: Pathophysiology, Presentation, and Management. Clinical Microbiology Reviews 2005, 18, 556-569, https://doi.org/10.1128/CMR.18.3.556-569.2005.

23. Rammaert, B.; Lanternier, F.; Zahar, J.-R.; Dannaoui, E.; Bougnoux, M.-E.; Lecuit, M.; Lortholary, O. Healthcare-Associated Mucormycosis. Clinical Infectious Diseases 2012, 54, S44-S54, https://doi.org/10.1093/cid/cir867.

24. Ibrahim, A.S.; Spellberg, B.; Walsh, T.J.; Kontoyiannis, D.P. Pathogenesis of mucormycosis. Clin Infect Dis 2012, 54 Suppl 1, S16-S22, https://doi.org/10.1093/cid/cir865.

25. C Chakrabarti, A.; Singh, R. Mucormycosis in India: unique features. Mycoses 2014, 57, 85-90, https://doi.org/10.1111/myc.12243.

26. Prakash, H.; Chakrabarti, A. Global Epidemiology of Mucormycosis. Journal of Fungi 2019, 5, https://doi.org/10.3390/jof5010026. 